This item was submitted to Loughborough's Research Repository by the author.

Items in Figshare are protected by copyright, with all rights reserved, unless otherwise indicated.

\title{
Rethinking territory
}

PLEASE CITE THE PUBLISHED VERSION

http://dx.doi.org/10.1177/0309132510385619

\section{PUBLISHER}

Sage (๑) The authors)

\section{VERSION}

AM (Accepted Manuscript)

\section{PUBLISHER STATEMENT}

This work is made available according to the conditions of the Creative Commons Attribution-NonCommercialNoDerivatives 4.0 International (CC BY-NC-ND 4.0) licence. Full details of this licence are available at: https://creativecommons.org/licenses/by-nc-nd/4.0/

\section{LICENCE}

CC BY-NC-ND 4.0

\section{REPOSITORY RECORD}

Antonsich, Marco. 2019. "Rethinking Territory”. figshare. https://hdl.handle.net/2134/16124. 


\title{
Re-thinking territory
}

\author{
Marco Antonsich \\ GEES, University of Birmingham, Edgbaston, Birmingham B15 2TT, UK
}

In a recent article for Progress in Human Geography, Stuart Elden (2010a) aims to bring conceptual and historical clarity to the question of 'territory' - a question that he wishes to keep theoretically distinct from the question of 'territoriality', which, either as a biological drive or as a social construct, lacks historical contextualization. To answer this question, Elden embarks on a conceptual-historical examination, searching also for the etymology of 'territory'. He finds that both the Latin words terra (earth, land) and territorium (agricultural lands surrounding and belonging to a town or an abbey/monastery) are relevant. Both highlight the politico-economic dimension of territory, i.e. its value as a commodity which can be owned along its natural resources. Yet, echoing the interpretation that reads in territorium the same root as in the verb terrere (to frighten), he maintains that territorium also highlights a political-strategic dimension, which can be best captured by the notion of 'terrain'. Neither land, nor terrain is, however, sufficient to understand territory, as this, according to Elden, is mainly dependent on two other dimensions: the political-legal and the political-technical. While the former refers to the ways in which territory is entangled with issues of sovereignty, jurisdiction, and authority, the latter refers to mapping and surveying techniques involved in its production. Elden's key point is that territory was historically made possible by the idea of a quantifiable and calculable geographical space, which much owns, according to 
him, to Descartes's analytical geometry. Within this understanding of space, it becomes apparent that boundaries do not define territory, since this latter is the product of a calculative sense of space upon which also the production of boundaries relies; boundaries are, therefore, a second-order problem. In conclusion, Elden affirms that territory can be understood as a political technology, comprising techniques for measuring land and controlling terrain.

While I certainly agree with Elden on the importance of locating the notion of territory in a historical context, I am not totally convinced by the analytical steps taken by Elden and his final characterization of territory as a technical device. I would like, therefore, to engage his account both from a methodological and a theoretical perspective in order to contribute to the 'territory debate', which, as Elden rightly affirms, has found so far very few (if any) commentators.

Methodologically, my concern is with the relevance of an approach which focuses more on a term than on an idea. It seems to me that Elden's analysis is driven more by a search for the historical meanings of 'territory' than by an investigation of the historical forms of 'bounded political space', which is the idea generally conveyed by the modern understanding of territory. I definitely see the importance of problematizing what 'bounded' and 'space' mean within this definition. Yet I think that, by privileging a term rather than an idea, Elden's theorization of territory leaves out examples of territorial formations before (and also after) the advent of modern territory. This is somewhat odd, because Elden himself acknowledges elsewhere (Elden, 2010b) that Caesar, in his De Bello Gallico, showed a clear sense of political control of land, set apart from other lands through boundaries (fines), although he never used the term territorium. Similarly, 
Elden's (2003) account of the spatiality of the Greek polis reveals a demarcated sociopolitical space also in the absence of any Greek term for territory. This last example is particularly significant since, as Elden shows, an arithmetical and geometrical calculation of space - the key factor, for Elden, in the emergence of modern territory - was present among the ancient Greeks too. Also later, in the $16^{\text {th }}$ and $17^{\text {th }}$ centuries, when the notion of territory according to Elden historically emerged, Northern Europe was still dotted with autonomous political communities anchored to geographically demarcated spaces regulated by customary laws which ignored the term territory, being instead called landschaften (landscapes) (Olwig, 1996). How to interpret these territorial formations which existed before, during, and after the emergence of territory in proper historical terms? Moreover, if one accepts that territory is a modern construct, what would the rationale be for looking, as Elden does, at how territory has been understood historically (as well as geographically)?

Elden is certainly not alone in associating the emergence of territory with the emergence of the modern state. More debatable is his emphasis on Descartes' analytical geometry. As Elden, in fact, recognizes, a calculative conception of space was already in place in Europe since the rediscovery of Ptolemy's Geography in the $14^{\text {th }}$ century. In addition, I wonder whether we should not investigate further the relevance of the linear perspective, theorized by Alberti in 1435, for the production of modern territory. It seems to me that this would offer an equally powerful conceptual basis for the idea of a political power which aims to master space from a single-point perspective - a sort of panoptic political gaze out of which modern territory is produced. 
Yet, I am not so much concerned here with the exact periodization and related techniques which made modern territory possible, but, as I said, with the existence of territorial formations before the emergence of modern territory. Thus, I wonder whether we should not introduce a broader conceptual category, the 'territorial', to study territorial formations before the advent of modern territory. While this latter term can be used to signify the territory of the modern state, built on the idea of linear boundaries and exclusive sovereignty, 'territorial' might instead refer to more broad historical examples of bounded political spaces, to be analyzed through a history of political institutions more than philology. Within this enlarged perspective, ‘bounded' would not necessarily stand for a linear boundary, but any geographically demarcated limit; similarly, the 'political' (a notion which, although addressed elsewhere by Elden, it is surprisingly left unaddressed in his essay) would not necessarily be epitomized by modern exclusive sovereignty, but alternative forms of socio-spatial authority and jurisdiction.

To be sure, the territorial should not be considered less historical a term than territory, since, at least with reference to Indo-European political institutions, there is evidence of a historical transition from a society structured along a genealogical principle to one structured along a territorial subdivision (Benveniste, 1969: 293, 309). Yet, in this context, the territorial would not necessarily be the product of calculable space and geometric coordinates, but, following the reading of pre-modern political institutions offered by Schmitt (2003), would emerge out of practices of land appropriation, division, and regulation, whether informed by geometrical knowledge or not. ${ }^{1}$ This interpretation would bring back the act of 'b-ordering' not as a second-order problem but a first-order one, rescuing it from too narrow a conception which would implicitly reduce the political 
to a mere technicality for measuring and surveying space. From this perspective, the passage by Cicero quoted by Elden (p. 8), for instance, would matter not so much for his use of territorium as agricultural land, but for the very act of b-ordering (the demarcation of a new colony with a plow), which goes unnoticed in Elden's philological search.

My aim here is not to campaign for a new notion (the territorial) in an intellectual market already saturated with contested categories (Jones, 2009). Two adjectives (modern/pre-modern) would equally serve the purpose - which is my aim here - of not reducing the 'bounded' to the linear boundaries of the modern state, thus ignoring other historical socio-spatial formations, in other geographical contexts as well (Sidaway et al., 2004), characterized by bounded political space.

There is something more, though, that relates to Elden's understanding of (modern) territory which deserves careful reading. His view of territory as a political technology for measuring and controlling geographical space (a definition which, incidentally, does not seem to me conceptually different from Sack’s (1986) notion of territoriality) is certainly relevant in today's world, where issues of security are increasingly managed in surveillance's terms. Yet, it is also a view strangely blind to the social dimension. It is true that in his essay Elden briefly mentions this dimension, as well as the cultural and the affective dimensions. Yet, he does not seem to believe that they are central to the definition of (modern) territory. If they were, they would in any case be so mainly in relation to the nationalization of territory, as Elden seems to suggest (p. 13). I would argue that this is a rather partial view because, first, it implicitly reproduces the idea of a close spatial isomorphism between the nation and the state which in a multicultural age has become even more problematic than in the past and, second, it ends up talking of 
(modern) territory mainly as a terror(izing) tool, where people are treated as homines sacri, waiting to be controlled, oppressed, or simply disposed (Antonsich, 2009). No agency is acknowledged on the part of people in the production of (modern) territory.

As a way to fill this gap and 'peopling' (modern) territory, it can instead be useful to look at other geographical traditions. In particular, Francophone geography (e.g., Raffestin, Bonnemaison, Debarbieux, Di Méo) has long theorized territory (territoire) as a social space, produced by specific social practices and meanings which turns territory into both a 'semiotized' and a 'lived' space. Within this perspective, territory is not a socially dis-empowering technical devise, but the socio-spatial context where the 'living together' is produced, organized, and negotiated through the continuous interplay between ‘top-down’ discourses and ‘bottom-up’ mundane practices and lived experiences. Although this territoire might at times coincide with local place, I believe that the francophone insights might also be fruitfully applied to (modern) territory.

As Elden rightly points out, a political theory of territory is still missing. His extensive genealogical work, which is due to appear in monographic format, promises to offer a key contribution toward its formulation. Yet, it certainly cannot exhaust the debate about territory/territorial. The hope is, therefore, that my comments will not remain an isolated voice.

\section{Acknowledgments}

Thanks to Virgilio Ilari, Veronica della Dora, and Francisco Klauser for their comments and feedback. 


\section{References}

Antonsich, M. 2009: On territory, the nation-state and the crisis of the hyphen. Progress in Human Geography 33, 789-806.

Benveniste, É. 1969: Le vocabulaire des institutions Indo-Européennes. Paris: Les Editions de Minuit.

Elden, S. 2003: Another sense of 'demos': Kleisthenes and the Greek division of the 'polis'. Democratization 10, 135-56.

Elden, S. 2010a: Land, terrain, territory. Progress in Human Geography doi:10.1177/0309132510362603, 1-19.

Elden, S. 2010b: From territorium to territory. Open University podcast: http://www.open.ac.uk/ccig/media/from-territorium-to-territory-talk-by-professorstuart-elden-at-ccig-forum-14

Jones, R. 2009: Categories, borders and boundaries. Progress in Human Geography 33, 174-89.

Olwig, K.R. 1996: Recovering the substantive nature of landscape. Annals of the Association of American Geographers 86, 630-53.

Sack, R. 1986: Human Territoriality. Cambridge: Cambridge University Press.

Schmitt, C. 2003: The Nomos of the Earth. New York: Telos Press.

Sidaway, J.D., Bunnella, T., Grundy-Warra, C., Mohammadb, Parka, B.-G., and Saito, A. 2004: Translating political geographies. Political Geography 23, 1037-49.

\footnotetext{
${ }^{1}$ This reading relies on Schmitt's (2003: 70) interpretation of nomos as the original act of land division (divisio primaeva) by which a people organize its property relations. As such, the nomos is associated with
} 
two interrelated concepts: Ortung (an occupied and delimited portion of the Earth) and Ordnung (the legal ordering of property relations and any other subsequent legal relations in this occupied and delimited portion of the Earth). 